\title{
PETROLOGY OF CONTINENTAL ROCKS
}

\author{
TOM. F. W. BARTH \\ Geological Museum, Oslo, Norway
}

The aim of petrology, as I see it, is to study the »beginning», development, alteration, intergradation, and the reconstruction of rocks. Geologists know that rocks are not so petrified and still as most people think, but full of movements and action. Much like a biological species, so a rock species has a »life» and a history from cradle to grave.

The continental rocks are, of course, the rocks that build up the continents - they occupy about one third of the surface of the earth and are different from the rocks of the ocean floors. They form a crust or just a skin, $30-40 \mathrm{~km}$ thick, floating on top of the sima of basic or ultrabasic composition. Under the ocean the sima ascends to within a few kilometers of the surface. Thus the continental rocks lie in extensive, shallow depressions in the simatic shell of the globe. A glance at figure 1 shows that the continental rocks represent a very minor part indeed of the globe.

Among the rocks of the continents, true eclogites and some other ultramafic rocks derive from the mantle of the earth and will only occasionally appear in the upper parts of the crust. As meteors are obvious messengers from outer space, occasionally to be found at the Earth's surface, ultramafics are messengers from inner space, i.e., from the interior of the earth. The continental rocks are thus somewhat contaminated by foreign materials. It is important to note this. Nature always produces rock

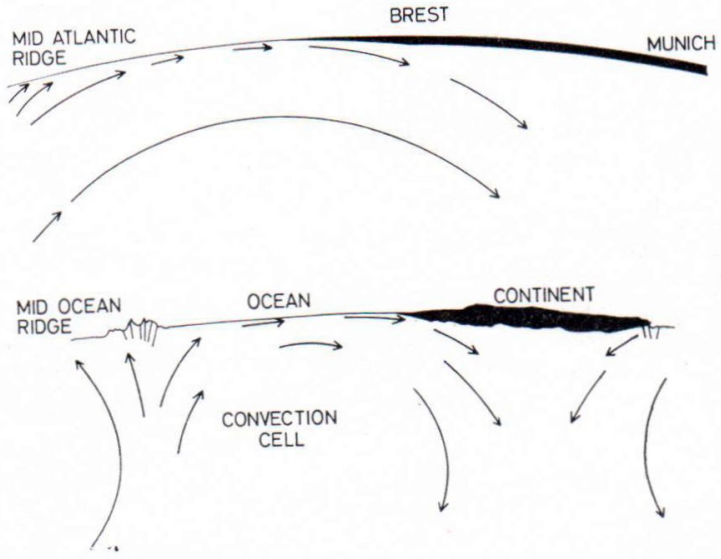

Fig. 1. Upper half: Section through part of the Earth drawn in correct proportions. The section is about $3000 \mathrm{~km}$ long and streches from the Mid Atlantic Ridge eastward to Munich in Germany. The continental crust (black, 30-40 km thick) is shown floating on the sima (white) which, due to convection currents, is in cyclic movement (indicated by arrows).

Lower half: Schematic section through ocean and continent. The currents of the convection cells are indicated. Not drawn to scale.

fractions that pass imperceptibly into other types of rock. Leaving these odds - and ends, I shall discuss the petrology or, to be more specific, the petrogenesis and metabolism in the continental crust.

What does contemporary geology say about the beginning and evolution of this thin layer of continental rocks portrayed in figure 1 ? The great majority of geologists seem to follow the lead of Rosenbusch - Clarke and Washington - Bowen - V. M. Goldschmidt. 


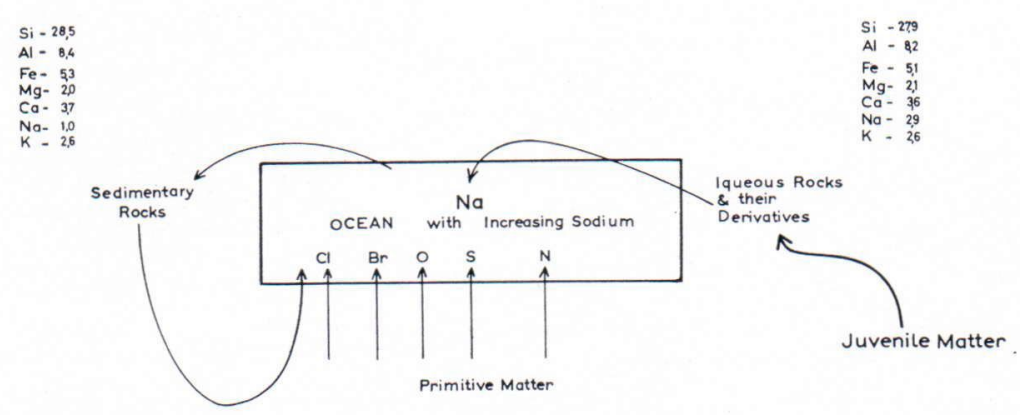

Fig. 2. The geochemical migration of the elements as conceived by Goldschmidt. The composition of the "crust of the earth" is tabulated in the upper right corner. The composition of the sediments is tabulated in the upper left corner. In between is the ocean which increases in sodium with time. Therefore the sodium content of the "sediments» is reduced to about one third of that of the crust.

Rosenbusch regarded the igneous rocks as primary rocks, they come from the depth of the earth, from »die ewige Teufe», i.e., they are »juvenile». Sedimentary and metamorphic rocks are derived from igneous material; in this respect they are secondary; but ultimately they too derive from the depths of the earth.

Clarke and Washington adhered to Rosenbusch's theory, and considered the crust as made up wholly of igneous rocks: »because the material of sedimentary rocks has been derived entirely, either directly or indirectly, from preexisting igneous rocks» (Washington 1920).

Bowen showed that a basaltic magma by crystallization fractionation can yield almost all igneous rock types found in the continent, and from that time, a major project at the Geophysical Laboratory has been »investigating the principal systems bearing on the nature of the (basaltic) magma from which evolves the great diversity of igneous rocks» (of the continents). (Abelson 1960).

W. M. Goldschmidt was also deeply rooted in the Rosenbusch school. He believed in juvenile igneous material which upon weathering was delivered into a sea which accumulated sodium. Therefore, the age of the sea and the "total» amount of weathering could be calculated from the present content of sodium in the sea. Goldschmidt's model is shown graphically in Fig. 2. It was accepted almost unanimously by geochemists in the western world.

In the leading article of the first issue of the new journal »Chemical Geology» (1966), Manten repeats all the old arguments and presents the sea as a receptacle for accumulating sodium.

A glance at figure 1 makes these theories almost ridiculous. How can a pancake of granitoid composition swimming in a sea of basalt (or peridote) remain a granitic pancake after having received all its material from the basaltic sea?

There were also dissenting voices: Vernadsky delivered a series of lectures on geochemistry, 1922 - 1923, at the Sorbonne, Paris. One important generalization of his was the full use of the cycles in geochemistry. "The great mass of matter in the continental crust is in a state of constant atomic movement and forms closed and reversible cycles which go round and round incessantly. At the surface the driving force is the energy of the sun - and in the depths the energy of the radioactive processes.» (Translated from page 401). 


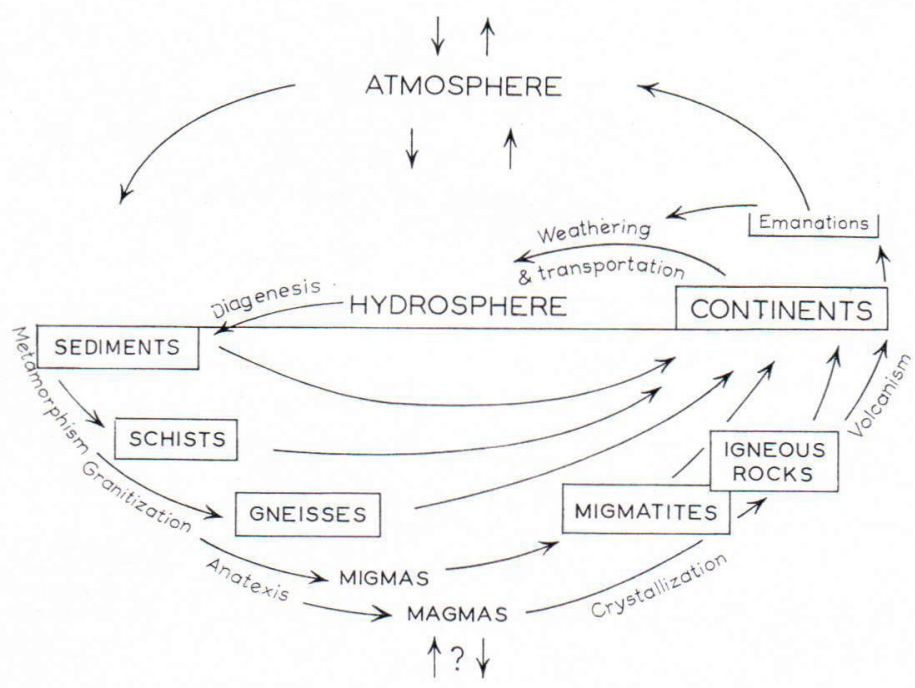

Fig. 3. The principle of the detailed geochemical cycles. A steady state is assumed based on a dynamic equilibrium. The chemical species of the weathered rocks are delivered into the sea, and by wreverse weathering» (MacKenzie and Garrels, 1966) they are precipitated and most of them deposited in the geosynclinal troughs.

By downbuckling and orogenic processes they are returned through the internal branch of the cycle into the metamorphic and igneous rocks of the continents.

In France the school of Perrin and Roubault (1937, 1939) was categorically against the views of Rosenbusch.

Nieuwenkamp of Utrecht in various lectures and publications since 1948 emphasized the importance of the cycles, and demonstrated historically how our interpretation of the cycles was influenced by mysteriously authorized notions, and how our ideas of rock genesis developed through many and often sinuous changes during the 200 years from James Hutton and his new champion, Charles Lyell, one of the greatest of geological thinkers, who had but scorn for the »molten beginning», which, nevertheless, soon became official truth.

The last decades have brought a change. The »truth» is no longer so solidly identified with authority; more sophisticated heretics have gradually invaded the literature. Forced to rethinking by the present immense accu- mulation of facts and observations, a number of younger geochemists have left the Rosenbusch-Goldschmidt school and actually adhere to views congenial to Hutton and Lyell.

The crucial point is that the continents have their own metabolism.

Continents float and spread out as thin layers. Sometimes they crack and the pieces drift apart. Non the less, the atmosphere, hydrosphere, and continents with their shelves form a close geological system with nearly closed cycles of destruction and construction. But under and between the continents the "sima» gurgles and contaminates the continents by infiltration (ophiolites and serpentinites of the initial geosynclinal volcanism?) or penetration (plateau basalts). However, because of their superior position in the gravity field the continents are able to rid themselves of this heavy material which, consequently, again sinks down in die ewige Teufe». 
In harmony with the endless geochemical cycles the sea is an open system: When the same material is going round and round, the volume of the existing sediments and the amount of salt in the sea have nothing to do with time.

Fig. 3 explains the endless geological cycles. A steady state prevails. The chemical composition of each rock group, the compositions of, for example, the average sediment or of average seawater do not change with time. v. Engelhardt (1959) has coined the graphical phrase: win der Entstebung und Wandlung der Gesteine herrscht eine immerwäbrende Gegenwart».

J. J. Sederholm, the great explorer and interpreter of the Fennoscandian Precambrian was seeking a floor upon which the sediments were deposited. He found no floor. He concluded that the oldest rocks are (meta)-sediments. Consequently, the sea is older than the oldest rocks. The cyclic principle cannot serve as a guide to the primitive state of the earth. For the sea and the continental crust are in a steady state: We have to assume a balance between input and output of all elements. See Fig. 3.

The continental rocks we see today have once been sediments; there is no "juvenile» material. The rocks have been modified by metamorphism, and by "plutonism»; they have been remelted, partly at least and have been in the form of magmas or lavas.

A rapid survey of the weathering may now be formulated as follows: Let $\mathrm{W}$ be the total mass of weathered continental rock in unit time. It will split into three parts: $\mathrm{W}=\mathrm{D}+\mathrm{S}+\mathrm{R}$.

$\mathrm{D}$ goes into ionic solution, $\mathrm{S}$ goes into suspension; both are delivered to the sea. $\mathrm{R}$ is the resistate which remains in the continent. $\mathrm{D}$ and $\mathrm{S}$ are reconstituted to form marine sediments: $(\mathrm{D}+\mathrm{S}=\mathrm{H}+\mathrm{P}+$ E.) $[\mathrm{H}=$ hydrolyzates (shale), $\mathrm{P}=$ precipitate (limestone) $\mathrm{E}=$ evaporite.

Recent estimates of the present rate of sedimentation on the continents and shelves (Livingstone 1963 a and b, Holmes 1965, Gregor 1967) are in the range $1.6-4.3 \mathrm{~kg} / \mathrm{cm}^{2} / \mathrm{Myr}$.
$\left(\mathrm{Myr}=10^{6} \quad\right.$ years; see Rankama, 1967). A reasonable figure is $3 \mathrm{~kg} / \mathrm{cm}^{2} / \mathrm{Myr}$. It corresponds to a depth of erosion of 11 meters per million years all over the earth. Or $44 \mathrm{~km}$ depth in 4 billion years. If the erosion is restricted to the present area of land, the depth becomes $150 \mathrm{~km}$.

Clearly the erosion never reached such depths. The figure simply proves that extensive recycling must have taken place. During the geologic history of our globe a total mass perhaps many times that of the present continental crust has been eroded, fragmented or dissolved, transported and laid down as sediment, and again returned to the continent by geological (orogenic) processes in the eternal geochemical circuit.

If the steady state model is strictly correct, all materials in and at the crust of the earth are interrelated; there is no juvenil matter, there are no losses: all rocks disintergrade and pass into sediments, the sediments change into metamorphites, plutonites, even lavas, which again become sediments.

Such interrelations must manifest in characteristic chemical parameters of the sea, the rivers, and of the various rock types concerned. The chemical parameters actually determined, strongly indicate that these interrelations exist. Balance sheets to show this, have been prepared by a number of geochemists, e.g. Barth (1962), Shimazu (1966). Generally speaking, the correspondence is good. But there remain two problems that, so far, could not be harmonized with the geological cycles as here presented.

(1) First, there is a marked discrepancy in the $\mathrm{Na}$ content of the igneous and metamorphic rocks on the one side, and the sediments on the other. All computations show that sediments are deficient in $\mathrm{Na}$. But as soon as the sediments are metamorphosed and pass into phyllites or schists they become rather high in $\mathrm{Na}$. This has been a bit of a mystery, for all other observations indicate that low-temperature metamorphism is chemically conservative; $\mathrm{Na}$ does not move during low-temperature conditions (Mehnert, 1960). 
The solution of this problem is that most geosynclinal sediments are altered and metamorphosed in their subaquatic locale at great crustal depths at the bottom of the geosynclinal trenches. The pore space of the sediments is in the range $10-20$ per cent, and the pores are filled with seawater, which is high in sodium. Sodium also utilizes the exchange capacity of the sediments; probably $0.1-0.2$ milli-equivalents of sodium is sorbed to each gram of the sediment. Sodium in this form is reactive; at slightly elevated temperature and pressure it reacts with the clayey material in whose pores it is present and enters into the minerals of the resultant metamorphites (phyllites, micaschists, and other pelitic rocks).

By uplift, some fresh sediments - but only a small fraction of the total mass - are returned to land, and the "mobile» sodium in the pores and on the grain surfaces is leached out. All chemical analyses of sedimentary rocks from which averages have been computed come from deposits leached in this way. Consequently, these analyses are irrelevant in conjuction with the geochemical sodium balance. The petrographers' sediments are not the parents of the petrographers' metasediments. It is wrong, therefore, to compare the average composition of sediments found at the surface with that of phyllites or micaschists, and conclude that sodium was introduced by metamorphism into the phyllites. For the source of the phyllite is not in our "usual» sediments, but in the fresh, sodium-rich deposits of the depths of the geosynclines. Thus the true parental sediments and the derived metamorphic rocks (the paraschists) have rather similar amounts of sodium (and of other chemical elements). No discrepancy actually exists, it was only appearant, because chemical analyses of the wrong kind of sediments used to be considered.

(2) The second objection is concerned with the huge quantity of pelagic sediments found on the deep sea floors. All these sediments come from the continents. Do they ever go back?
Extraneous material is found in the continents, similarly some continental material may go astray and settle for good in a foreign environment. Nature does not make absolutely perfect cycles. However, recent observations and theories indicate that the major part of the continental matter thus swept into the deep sea is not permanently lost.

The feed-back mechanism can be explained by a new almost sensational concept known as the "Sea-floor Spreading». The idea was implicit in the writings of some of the early proponents of continental drift, but it was formulated explicitly and in modern guise by American geophycicists; a particularly attractive version was presented by Dietz (1961).

The hypothesis of sea-floor spreading is simply that the floor is moving away from the midocean ridges, i.e., toward the continents.

Only within the last few years have sufficient data become available for assessing the merits of the hypothesis; see e.g. Ewing et al. (1966). A striking fact is that a midocean ridge in many respects acts as a mirror plane (plane of symmetry). - Let us look at the Mid Atlantic Ridge: the east and the west ocean halfs are mirror images of each other. Most striking are the magnetic anomalies that parallel the ridges; there is excellent matching on opposite sides of the ridges of patterns of normal and reversed magnetization; and the chronology of the magnetic pattern across the ocean parallels the chronology worked out on land and from deep-sea cores. The analogy of the ocean floor acting as a very large magnetic tape on which magnetic events have been recorded, the tape now being played back, seems appropriate. In addition, the patterns of heat flow anomalies, and the location of fault-plane solutions of earth quakes seem to be consistent with the concept.

The age pattern of the sediments is also extremely interesting. The oldest sediments are Jurassic, they are found close to the continents. Toward the midocean ridge they gradually become younger, with the youngest close to the 
ridge. The measured rate of spreading is about $1 \mathrm{~cm}$ per annum - extrapolation back to zero ocean width gives 190 Myr.

The mechanism of this movement may be understood by studying the sequence of crustal layers beneath the oceans; it is markedly different from that beneath the continents, and is quite simple: On an average $4.5 \mathrm{~km}$ of water overlies $0.30 \mathrm{~km}$ of unconsolidated, and $2.0 \mathrm{~km}$ of lithified sediments mixed with some volcanics. The total mass of these sediments corresponds to about $10 \%$ of the entire continental masses. - Beneath this is a layer ( $5 \mathrm{~km}$ thick) commonly called the basalt layer, whose bottom marks the Moho discontinuity.

The driving force of the sea-floor spreading must reside in deeper levels and can logically be connected with the large convection cells of the deeper mantle. These cells have dimensions of several thousands of kilometers. Heat flow measurements indicate that the midocean ridges mark up-welling sites, the continental margins the down-welling sites; and the fracture zones mark shears between regions of slow and fast creep. Since the sea floor is covered with only a thin veneer of sediments, it is essentially the outcropping mantle. So the sea floor marks the tops of the convection cells; the floor is riding on the back of the current - as it were - and is slowly dragged from the zones of upwelling to those of down-welling. See Fig 1.

The continental blocks, floating on the sima, provide a density barrier to convection circulation. The convection currents thus shear beneath the continents which are only partially coupled through drag forces. Thus marine sediments, seamounts, and other structures slowly impinge against the continental blocks and are destroyed by underriding them.

Thus, in a rather dramatic way, will the farflung sediments of the deep sea floors slowly find the way back to their native continents.

In this way the main obstacles for accepting the model of the endless geological cycles disappear. The same material, the same ions and atoms, go round and round, and although there is some contamination by foreign matter, it seems that in the long run the cycles are very nearly closed, there is no loss and no gain large enough to detract from the importance of the cyclic principle.

For the study of the origin and evolution of rocks in the continents, this is of fundamental importance; it is not the basaltic magma, but mixtures of natural sediments, that represent the mother material from which evolves the great diversity of the igneous rocks.

\section{REFERENCES}

Abelson, P. H. (1960) Ann. Rpt. Geophys. Lab. Canregie Inst. Year Book, 59, 44.

BARTH, T. F. W. (1961) Ideas on the interrelations between igneous and sedimentary rocks. Compt. rend. Soc. géol. Finlande, 33, 321.

- (1962) Die Menge der Kontinentalsedimente und ihre Beziehung zu den Eruptivgesteinen. N. Jahrb. Mh. 59.

Clarke, F. W. (1924) The data of geochemistry. 5th Ed. U. S. Geol. Survey Bull., 770.

Conway, E. J. (1942) Mean geochemical data in relation to oceanic evolution. Proc. R. Irish Acadæ, 1942.

Dietz, R. S. (1961) Continent and ocean basin evolution by spreading of the sea floor. Nature, 4779, 954.
Engelhard, W. von (1959) Kreislauf und Entwicklung in der Geschichte der Erdrinde. Nova Acta Lopoldina, $21,85$.

Ewing, J., Worzel, J. L., Ewing, M. and Windish, C. (1966) Ages of horizon A and the oldest Atlantic sediments. Science, 154, 1125.

Gaertner, H.-R. von (1951) Über die Alkali-Quelle der Granitisierung. Zeit. Deutsch. Geol. Ges., $103,7$.

Gregor, C. B. (1967) The geochemical behaviour of sodium. Dissertation Univ. Utrecht, 13. 2. 1967.

Holmes, A. (1965) Principles of Physical Geology. 2nd Ed. Edinburgh, 1965. 
Livingstone, D. A. (1963a) Chemical composition of rivers and lakes in Data of Geochemistry U. S. Prof. Paper $440-\mathrm{G}$.

- (1963) The sodium cycle and the age of the ocean. Geochim. et Cosmochim. Acta, 27, 1055.

MacKenzie, F. T., and Garrels, R. M. (1966) Chemical mass balance between rivers and oceans. Amer. Jour. Sci., 264, 507.

Manten, A. A. (1966) Historical foundation of chemical geology and geochemistry. Chem. Geol., 1, 5.

Mehnert, K. R. (1960a) Zur Geochemie der Alkalien im tiefen Grundgebirge. Beitr. Mineral. u. Petrograph., 7, 318.

- (1960b) Das Problem des Alkalihaushalts im Orogen. Geol. Rundschau, 50, 124.

Nieuwenkamp, W. (1948) Geochemistry of sodium. XVIII Int'l Geol. Congress, London Pt. 2, 96.

- (1955) Tableau de théories pétrogénétiques. Colloque Int'l Pétrograph., Nancy, p. 295.

- (1965a) Korrelation von Sediment und Eruptivgesteinen. Verh. Knkl. Nederland Geol. Mijnb. Genootschap, 16, 1.
Nieuwenkamp, W. (1956b) Géochemie classique et transformiste. Bull. Soc. Géol. France, 6, 407.

Orowan, E. (1966) Age of the ocean floor. Science, 154, 413.

Perrin, R., and Roubault, M. (1937) Les réactions à l'état solide et la géologie. Bull. Serv. Carte Géol. Algérie, 5e sér. Pétrographie, No. 1.

Perrin, R., and Roubault, M. (1939) Le granite et les réactions à l'état solide. Idem. No. 4.

Rankama, K. (1967) Megayear and Gigayear: Two unitsof geological time. Nature, 214, 634.

Rubey W. W. (1951) Geologic history of sea water. Bull. Geol. Soc. Amer., 62, 1111.

Shrmazu, Y. (1966) A dynamic model of geochemical cycle. Inst. Earth Sci., Nagoya Univ., Japan.

Vernadsky, W. (1924) La Géochemie (Félix Alcan, Paris).

WAshington, H. S. (1920) The chemistry of the earth's crust. Jour. Franklin Inst., 190, 757.

Manuscript received, May 6, 1968. 